Article

\title{
Assessing the Direct Resource Requirements of Urban Horticulture in the United Kingdom: A Citizen Science Approach
}

\author{
Miriam C. Dobson * (D), Philip H. Warren and Jill L. Edmondson (D) \\ Department of Animal and Plant Sciences, The University of Sheffield, Sheffield S10 2TN, UK; \\ p.warren@sheffield.ac.uk (P.H.W.); j.edmondson@sheffield.ac.uk (J.L.E.) \\ * Correspondence: miriamcdobson@gmail.com
}

Citation: Dobson, M.C.; Warren, P.H Edmondson, J.L. Assessing the Direct Resource Requirements of Urban Horticulture in the United Kingdom: A Citizen Science Approach. Sustainability 2021, 13, 2628. https://doi.org/10.3390/su13052628

Academic Editor: Ali Mohammadi

Received: 14 January 2021

Accepted: 26 February 2021

Published: 1 March 2021

Publisher's Note: MDPI stays neutral with regard to jurisdictional claims in published maps and institutional affiliations.

Copyright: (c) 2021 by the authors. Licensee MDPI, Basel, Switzerland. This article is an open access article distributed under the terms and conditions of the Creative Commons Attribution (CC BY) license (https:// creativecommons.org/licenses/by/ $4.0 /)$.

\begin{abstract}
Interest in urban food production is growing; recent research has highlighted its potential to increase food security and reduce the environmental impact of food production. However, resource demands of urban horticulture are poorly understood. Here, we use allotment gardens in the United Kingdom to investigate resource demands of urban horticultural production across the country. We conducted a nationwide citizen science project using year-long allotment 'diaries' with allotment gardeners $(n=163)$. We analysed a variety of resources: transportation; time; water use; inputs of compost, manure and topsoil; and inputs of fertilisers, pest control and weed control. We found that, overall, an allotment demands 87 annual visits, travelling $139 \mathrm{~km}$ to and from the plot; 7 fertiliser additions; 4 pest control additions; and 2 weed control additions. On average, each kilogram of food produced used 0.4 hours' labour, $16.9 \mathrm{~L}$ of water, $0.2 \mathrm{~L}$ of topsoil, $2.2 \mathrm{~L}$ of manure, and 1.9 L of compost. As interest in urban horticultural production grows, and policy makers build urban horticultural spaces into future sustainable cities, it is of key importance that this is carried out in a way that minimises resource requirements, and we demonstrate here that avenues exist for the diversion of municipal compostable waste and household-level city food waste for this purpose.
\end{abstract}

Keywords: United Kingdom; allotments; urban agriculture; energy; sustainability; cities

\section{Introduction}

The urban population of the world is rising, and is predicted to continue to do so over the next few decades [1]. Increasing urban populations highlight the need to understand and plan for the issues underpinning the sustainability of urban systems. Food is one of these. Cities are dependent on international food supply chains, which are vulnerable to shocks in the global system such as the 2020 coronavirus pandemic and the 2008-2009 food price crisis [2]. In many cities across the world, there is developing interest in the potential of urban horticulture (UH) to build resilience to such shocks. UH is the production of fruit and vegetables taking place in urban areas. It could also improve the environmental footprint of urban food consumption [3] and create opportunities for other social and environmental benefits associated with UH [4]. Research into mechanisms and opportunities for upscaling the amount of food production taking place within city limits has recently found promising results regarding potential food provisioning $[5,6]$. Some cities already produce a large proportion of their fruit and vegetable needs within the city limits; for example, Shanghai produces $60 \%$ of the vegetables consumed by its residents [7]. Many other cities now include some reference to UH within their sustainability planning, and networks of cities interested in scaling up urban food production are increasingly popular. The Milan Urban Food Policy Pact has 210 city signatories [8], and the UK's Sustainable Food Cities network has 52 [9]. There is also a large body of research demonstrating that UH can provide co-benefits alongside food production, such as improved health and wellbeing, educational 
and nutritional literacy, respect for and awareness of the natural world, and the delivery of ecosystem services [10-15].

An underlying assumption of the above research, and general increase in interest in $\mathrm{UH}$ in cities in the global North, is that UH offers a form of fruit and vegetable production that has many benefits not found in conventional horticulture; it may, at the same time also be more sustainable. The nature of much UH activity, which takes place informally, at small scales, and in different settings (unlike conventional horticulture taking place commercially at larger scales), means that the energy and resource flows associated with it have not commonly been integrated into citywide systems thinking [16]. There are many forms of $\mathrm{UH}$ with correspondingly varied resource demands [17]. What we do know about resource demand is limited to very few analyses, such as Life Cycle Analysis (LCA) on integrated urban farms, soil-less systems or rooftops [16,18,19]. However, most UH is small-scale, soil-based, activity, and has received little attention from this point of view; a single garden was used as a case study for an LCA in Italy [20], but representative, more geographically ranging multiple case studies have not been undertaken. Two studies which addressed this issue from a systems approach have both identified the need for careful consideration of technologies and policies promoting urban food production, to ensure they do not lead to increased resource demands in the urban system [21,22].

In this paper, we investigate the year-round resource demands of allotment gardening in the UK. Allotments are the most significant form of UH in the UK [23,24], and also form a large proportion of UH land across the European continent [13]. Allotment 'plots', typically $250 \mathrm{~m}^{2}$ land parcels, are rented by individuals or families from local councils or private landowners, and plots are grouped together on larger sites comprising anything from fewer than ten to over one hundred plots. There are approximately 330,000 allotments plots in the UK [25], and allotment sites as a whole use $82 \%$ of their land for plots, with the remaining used for associated infrastructure such as vehicle access [26]. Recent research has demonstrated that allotment gardening has the potential to be a highly important form of UH. One case study analysis found that it could provide fruit and vegetables for 3\% of a city's population despite allotments covering less than $1.5 \%$ of the city's area [26]. Demand for allotments is rising [27], with an average of 52 people on waiting lists for every 100 plots in the UK [25], and evidence suggests that the COVID-19 pandemic is further increasing demand for growing space [28]. It is therefore timely to develop our understanding of what the associated resource costs of allotment gardening are. We need to assess the sustainability of this form of UH, and identify opportunities for "urban symbiosis" (the potential to use resources otherwise wasted in the urban system, such as rainwater or organic waste) [17], so future developments of UH land can be integrated into cities in a way that enhances the sustainability of resource use.

There are a number of ways in which integration of UH might contribute to enhanced urban sustainability. For example, increasing kitchen waste compost for use in UH and redirecting excess rainfall for growing purposes could not only lead to a reduction in greenhouse gas emissions but also a reduction in costs associated with landfill management, water demand and flood mitigation [29,30]. According to the United States Environmental Protection Agency [31], 28\% of household waste sent to landfill is potentially compostable. On average, over $16 \mathrm{~kg}$ of vegetables are wasted per year per capita across the world [32]. Producing food locally, and composting waste, has the potential to reduce overall food waste as well as lower the emissions associated with food spoilage occurring during transportation $[19,29,32]$. The built infrastructure of urban environments also provides considerable potential for rainwater harvesting; it is estimated that Munich could save $26 \%$ of its current freshwater supply by harvesting rainwater [33]. If this were integrated into $\mathrm{UH}$, better management of rainwater run-off and a reduction in demand on the water supply could benefit both UH and the overall fabric of an urban area. There is widespread agreement that development and protection of urban green infrastructure, including $\mathrm{UH}$, can contribute to sustainability of urban systems, for example through the mitigation of the urban heat island effect $[30,34]$. There is also some evidence that greenhouse gas emissions 
reductions from expanding $\mathrm{UH}$ are greater than the sequestration potential of other urban greenspaces, based on LCA results [18].

We know from previous research that allotment gardeners tend to use management practices conducive to the maintenance of highly productive soils: in one study [35], 75\% of respondents added manure, $95 \%$ composted on their plot, and commercial composts and organic fertilisers were also used. However, the challenge remains to quantify these resources and investigate their origins. There has been no research to date quantifying other resource demands of allotment gardening, such as transportation, time commitments and water use. In light of this, it is clearly important to compile an evidence base of the resource demands of $\mathrm{UH}$.

Here, we use a year-long citizen science project, with allotment gardener participants from England and Wales, to establish the resource use requirements of UH annually. Citizen science is a unique way to collect data in collaboration with members of the public through their active participation in the research process. Here, the volunteer citizen scientists participated by recording their activities on their allotments for every visit over the course of a calendar year. This is an ideal method to answer questions such as those regarding resource use on allotments. Allotments are heterogeneous, small-scale land parcels, and allotment gardening practices are highly dependent on the time, interests, knowledge and proclivities of the individual allotment holders. The wider coverage, and large sample size possible with a citizen science approach lends itself well to establishing the range and variation of such practice. Approaches such as LCA (above) would require much more detailed investigation, and hence a far smaller sample size. The wider citizen science approach here is an important precursor to such, more detailed, approaches. The citizen science approach allowed us to go beyond a small number of case studies (e.g., [18]), and to gather data from across the country, providing good representation of allotment practices overall, as well as demonstrating the variations that exist among gardeners' practices. This has enabled a first understanding of the resource costs associated with allotment gardening, in addition to current levels of resource recycling.

We have also identified the opportunities to further increase the sustainability of allotment gardening through increasing the amount of waste and renewable resources used in this form of UH. This illustrates the potential for integration of UH into whole-system flows of food, energy and water to contribute to the sustainability of urban areas as a whole.

\section{Materials and Methods}

Citizen science participants, all of whom were allotment gardeners, were recruited through online advertising: Facebook, the MYHarvest website (https: / / www.myharvest. org.uk, accessed on 1 March 2021), and the National Allotment Society. Recruitment was also carried out in print in the Royal Horticultural Society magazine, and through posters attached to allotment site gates, which were posted to any volunteer who expressed an interest in recruiting other members of their allotment site. In total, 437 participants were recruited with a geographical spread across England, Wales, Scotland and Northern Ireland.

The UK has an average annual minimum and maximum temperature of 5.3 and $12.4^{\circ} \mathrm{C}$, respectively. Average monthly rainfall in the UK is $96 \mathrm{~mm}$, and average monthly sunshine is $114 \mathrm{~h}$ [36]. The growing season is, on average, 270 days long [37]. It is worth noting, however, that conditions in urban allotment gardens may vary from the average due to factors such as the urban heat island effect [30,34].

Volunteers were sent an allotment "diary", with a separate page to fill out for each allotment visit (Figure 1). They were asked to fill their diary out each time they visited their allotment, for a full year, with participant recruitment and therefore start date spanning December 2017 to March 2018. Participants were also asked a number of general questions about their allotment, including length of tenancy, whether they grew organically, use of peat free compost, number of people working on the plot, and yearly rent prices 
(Supplementary Materials). A pilot study was first conducted with volunteer gardeners on an existing citizen science project to refine the diary pages.

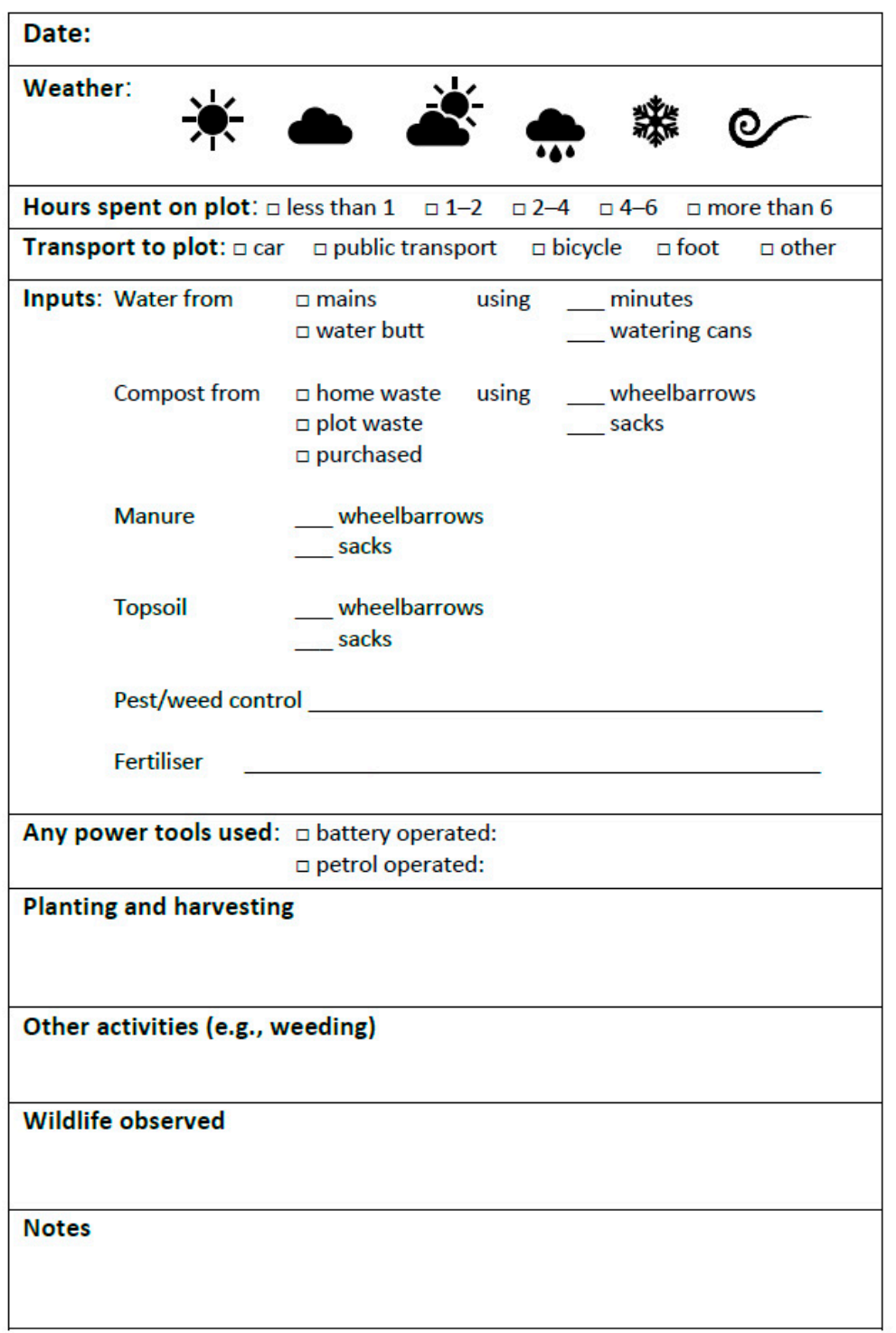

Figure 1. Recording sheet for participants in the allotment diary project. Copies of the same sheet were filled out every time gardeners visited their allotment over the course of a year.

On each allotment visit, participants recorded the activities they undertook. This included the date; the weather; the method of transport used to get to the allotment; how long they spent on their plot; quantification of water use from the mains or from water butts (rain water containers) in number of watering cans, or minutes of hosepipe time; compost, manure and topsoil additions (in number of wheelbarrows or sacks used); any use of fertilisers, pesticides or weedkillers; planting, harvesting and other activities; wildlife observation; and any other notes they felt they wanted to share. For the purposes of this paper, we focus on the resource inputs recorded by participants. This includes transportation, number of hours spent on the plot, water, compost, topsoil, manure, and other additions.

At the end of the year, participants were sent a stamped addressed envelope to return their diary pages. The returned diary pages were then scanned (so that originals could be returned to those who had requested this) and data were extracted. The mid-point of each option for the number of hours spent on the plot was taken to analyse total and average 
time spent working on the allotment. Google Maps was used to work out the distance from a participant's house to their plot. Specific parts of data had to be discounted from some participants, for example two of the participants who did not record any water use for an entire year.

One hundred and sixty-three participants (37\%) returned their diaries, detailing a total of 14,992 individual allotment visits. Most returns were from England, despite a wider geographical spread of initial participants, which reflects the proportional spread of the initial recruitment (Figure 2). All diaries returned covered a full twelve-month period, apart from one which spanned February to October only, for health reasons, and this was excluded from estimates of year-round inputs but included when analysing on a month-by-month basis. A further two returned diaries were immediately excluded from our analyses due to incompleteness.

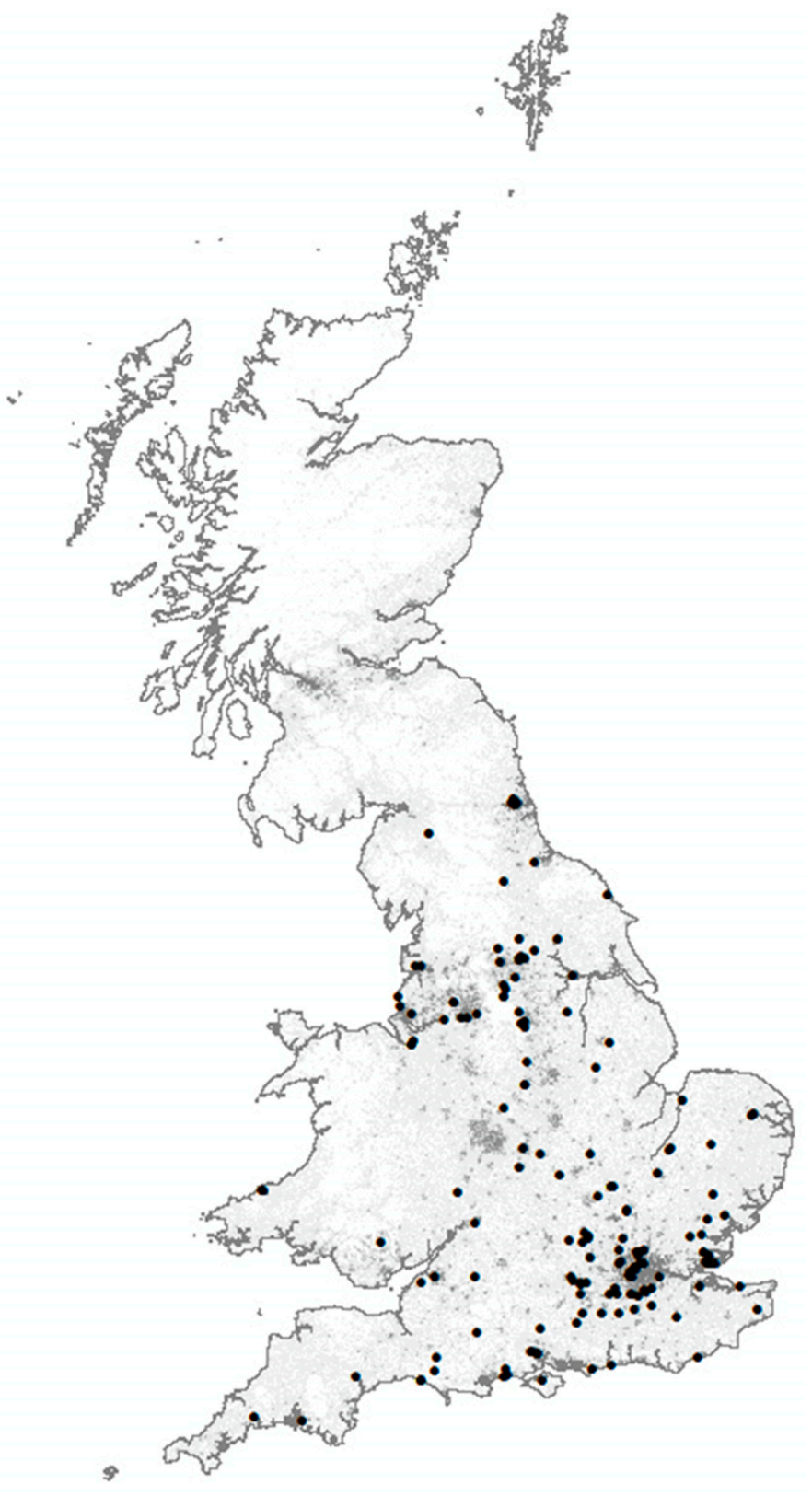

Figure 2. Distribution of allotment diary participants who returned their diary across Great Britain (black dots) and population density (shading) [38]. 
As is typically the case with citizen science initiatives, we had to compromise between the detail of information people were asked to supply, and the willingness of participants to record information on every visit for an entire year. We therefore adopted a system of quantifying many aspects of resource use in simple, and easily recorded, forms, accepting some sacrifice of precision in individual estimates. We surveyed volunteers from the MYHarvest citizen science project (https: / / www.myharvest.org.uk, accessed on 1 March 2021) to estimate typical sizes of watering cans. From 207 respondents who told us the size of their watering can, the median (9 L) was used. Average sizes of wheelbarrows and compost sacks (where participants had not quantified this themselves) were estimated by sampling popular items on garden centre websites. Probable hosepipe flow, in litres per minute, was estimated using information from Swanhose [39]. Pesticide, fertiliser and weedkiller use was unquantified beyond whether it had been used on a visit or not. Participants were asked to name the type or brand of each of these inputs when they used them.

We calculated our estimates for the average yearly resource requirements of allotment gardening by using the typical allotment plot size of $250 \mathrm{~m}^{2}$. Not all of an allotment is cultivated for food production, with a proportion being impermeable surface such as paths and sheds, and a proportion being permeable uncultivated surfaces such as grass areas. The intensity with which each area is managed varies and the food production areas can be assumed to use the majority of resources, but time is also taken to manage the overall allotment and spend time in relaxation. It is unlikely that a gardener would have only food growing area and no other type of land use on their allotment; therefore, we have chosen to treat the plot as a whole rather than divided into individual land use types.

Statistical analysis was conducted in $\mathrm{R}$ version 4.0.0 [40]. As data in many cases did not conform to the assumptions of parametric tests, all analyses were carried out using non-parametric techniques: Kendall's tau for bivariate correlations, and Kruskal-Wallis tests to compare groups.

\section{Results}

\subsection{General Characteristics of Allotment Gardeners}

Participants' homes were between 0 (an allotment backing on to a residential property) and $9.2 \mathrm{~km}$ away from their allotment plots; however, the distribution of distances was skewed and the median distance that people lived from their plot was $1.6 \mathrm{~km}$. Participants had worked their plot a median of 6 years, with a range from zero years (one person who was a new tenant on their plot) to 47 years. Of participants who answered the question of whether they cultivated organically $(n=159), 88(55 \%)$ did, $45(28 \%)$ grew mostly organically, and $26(16 \%)$ did not. Most participants worked their allotment alone, with $97(61 \%)$ being the sole worker on their plot, 61 (38\%) sharing the work with one other person, and one respondent having two additional co-workers. The median yearly rent for an allotment was $£ 37$, with rent ranging from $£ 0$ (two participants) to $£ 280$ (a site in London). Overall, only $7 \%$ of respondents paid over $£ 100$ a year.

\subsection{Time Commitment}

We included 161 diaries in our analysis of time commitment. The median number of hours spent on the allotment over the course of a year was 150 (with a range from 22 to $647.5 \mathrm{~h}$ ), with a median of 87 visits. The total number of visits across the year ranged from 30 to 204 . The median visit length was $1.5 \mathrm{~h}$. In winter (December, January and February), $30 \%$ of time spent on the plot and $26 \%$ of visits to the plot took place. In spring (March, April and May), 39\% of time and $42 \%$ of visits took place. In summer (June, July and August), 21\% of time and 21\% of visits took place. In autumn (September, October and November), $10 \%$ of time and $12 \%$ of visits took place. The time spent visiting was greatest in May and June, but the largest number of visits was in July. There was no statistically significant correlation between the total number of visits made over the course of a year 
and the distance people lived from their allotment (Kendall's tau, tau $=-0.01, \mathrm{Z}=-0.20$, $p=0.84$ ).

\subsection{Transportation}

Transportation to the allotment was split between bicycle, car, foot, public transport, and "other" (which included one motorcycle journey, and the rest of unknown type). 158 diaries were included in this analysis. In total, $56 \%$ of journeys were made by car, $36 \%$ by foot, $8 \%$ by bicycle, $0.4 \%$ by public transport, and $0.05 \%$ by "other". The typical distance travelled differed with statistical significance between different forms of transport (Kruskal-Wallis test, $\mathrm{H}=32.8, \mathrm{df}=4, p<0.0001$ ). The median car journey length was $1.6 \mathrm{~km}$, and the distribution of car journey lengths was strongly skewed due to people who lived unusually far from their allotment plots (See Section 3.1). The median walking journey distance was $1 \mathrm{~km}$, and the median bicycle journey distance was $1.3 \mathrm{~km}$. Ninetyfive percent of walking journeys were under $2.1 \mathrm{~km}$ (according to Google Maps, this is approximately half an hour of walking time). Walking and cycling was most popular if people lived less than $5 \mathrm{~km}$ from their allotment $(n=141)$. Over $5 \mathrm{~km}$, most people were dependent on car travel $(n=17)$, with the maximum walking journey length being $8.0 \mathrm{~km}$ and the maximum cycling journey length $4.2 \mathrm{~km}$, but the maximum car journey length $9.2 \mathrm{~km}$ (Figure 3).

A
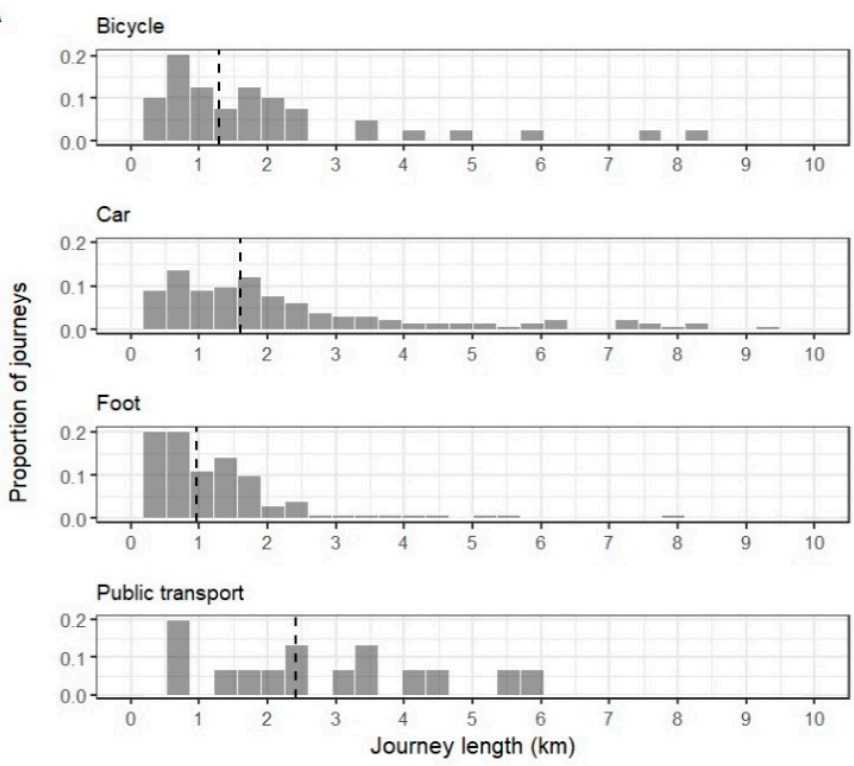

B

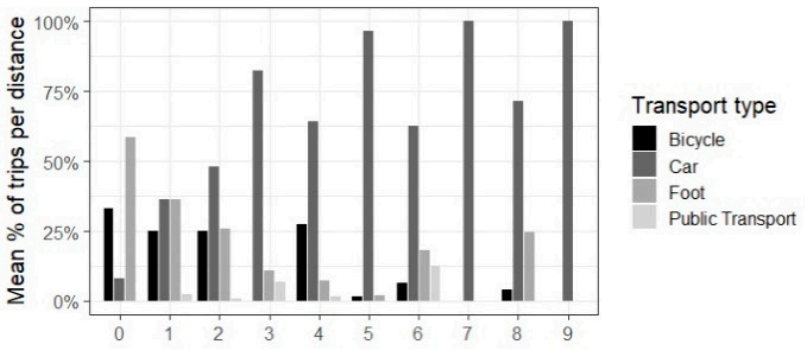

C

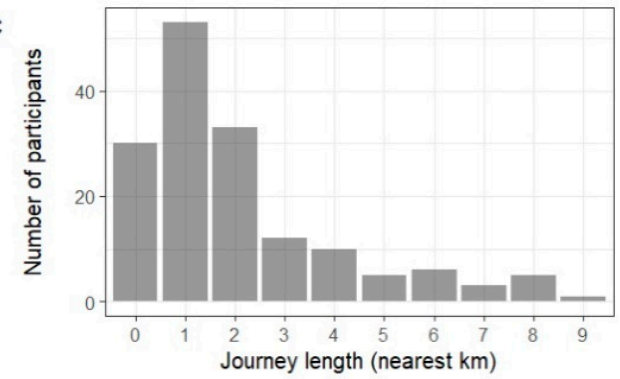

Figure 3. Graphs showing variation in use of different transport models and distances travelled from home to plot by allotment gardeners $(n=158)$. (A) Distribution of journey lengths for each transportation type (bicycle, car, foot and public transport); (B) distribution of transportation type for each $\mathrm{km}$ travelled; (C) distribution of distance travelled by participants, not split by transportation type.

\subsection{Water Use}

Water use was highly variable amongst the 149 participants included in this analysis and ranged from $288 \mathrm{~L}$ over the course of the year to $120,013 \mathrm{~L}$. The median annual water use on an allotment was $7595 \mathrm{~L}$, and the data were heavily skewed towards people who used a substantially greater amount of water on their plot. The median annual amount of water used from water butts (which also included other non-mains sources of water, such as river water) was $486 \mathrm{~L}$, and the median amount of water used from the mains was 5993 L (Figure 4). 
A
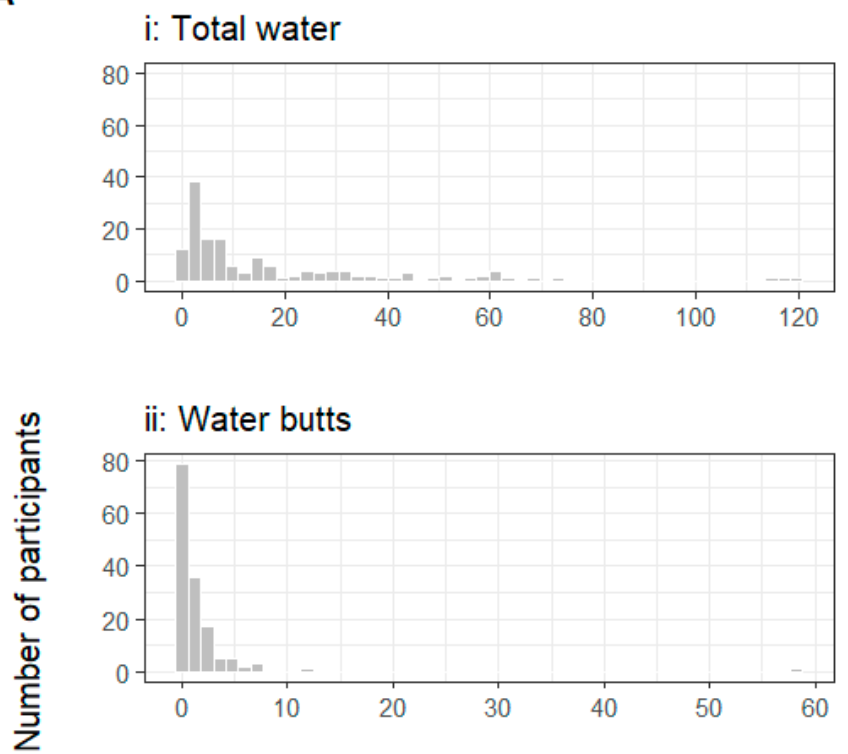

iii: Mains

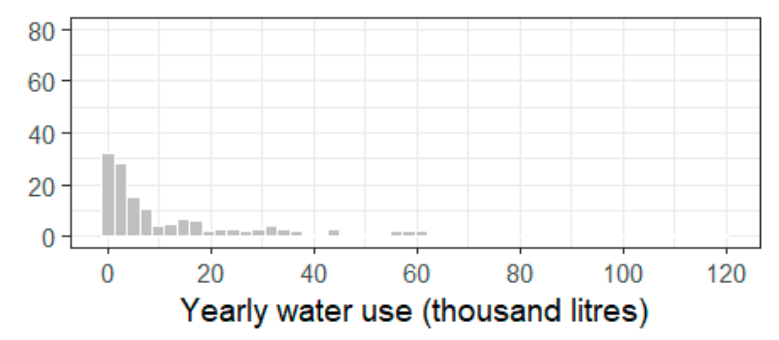

B

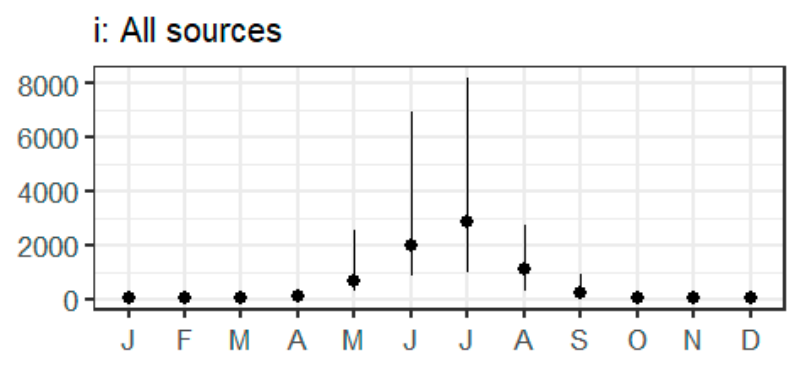

ii: Water butts

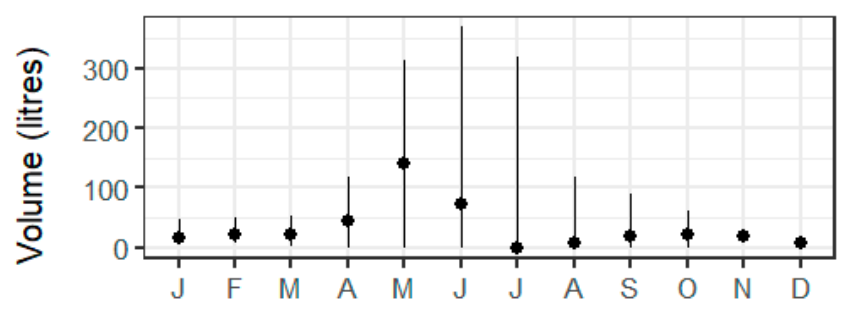

iii: Mains

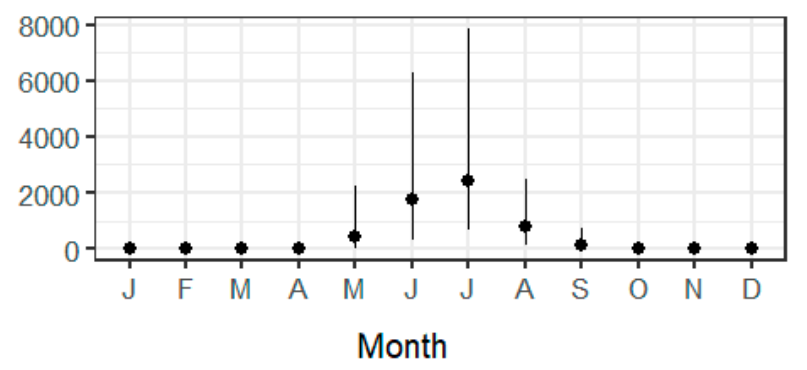

Figure 4. Water use by allotment gardeners $(n=149)$ over the course of a year. (A) Total water use, water from water butts, and water from mains supply. Dashed lines indicate the median water use, for (i) $7595 \mathrm{~L}$; (ii) 486 L; and (iii) 5993 L. (B) Monthly median (points) and interquartile ranges (lines) of litres of water used on allotments from water butts, mains water, and all sources.

The types and total amounts of water used varied by month (Figure 4). Overall, $13.2 \%$ of water use occurred in spring, $80.8 \%$ in summer, $5.7 \%$ in autumn and $0.1 \%$ in winter. In spring, $11.8 \%$ of mains and $26.6 \%$ of collected water was used. In summer, $82.4 \%$ of mains and $65.5 \%$ of collected water was used. In autumn, $5.7 \%$ of mains and $7.0 \%$ of collected water was used. In winter, $0 \%$ of mains and $0.4 \%$ of collected water was used. There was a peak in the use of water butt water in May followed by a decline in June and none used in July, and a corresponding increase in the amount of mains water used in June and especially in July as a result. Water butts provide a limited storage for water, and dry conditions meant that they were used up before the peak of the summer (see Discussion below for a discussion of the weather conditions of 2018). The small increase in water butt water usage in the autumn can be interpreted as people going back to using collected water once rain had replenished supplies.

\subsection{Compost, Manure and Topsoil}

One hundred and thirty-three (86\%) participants added compost to their plot; 110 (71\%) added manure, and $26(17 \%)$ added topsoil. The median total annual amount of compost, manure and topsoil added to an allotment plot was $1575 \mathrm{~L}$. The median amount of compost per year added by people who used compost was $850 \mathrm{~L}$; the median use of manure by manure users was $992 \mathrm{~L}$; and the median use of topsoil by topsoil users was $85 \mathrm{~L}$ (Figure 5). However, when considering all participants ( $n=155$ for this analysis) rather than just those using each of these inputs, the median amount of compost was $688 \mathrm{~L}$; manure was $275 \mathrm{~L}$ and topsoil was $0 \mathrm{~L}$. We asked participants to disclose the origins of the 
compost they used: council waste comprised $5.3 \%$ of the total volume of compost applied by all our participants, home food waste $23.8 \%$, plot waste $54.6 \%$, and purchased compost $16.1 \%$. Therefore, $83.9 \%$ of compost used by volume was recycled material, whether from the home, garden or local council. Many respondents used a mixture of sources for their compost, and overall $76(49 \%)$ participants brought home waste to their plot to compost, $92(59 \%)$ purchased compost, and $94(61 \%)$ composted plot waste. Of participants who answered the general question regarding whether they used peat free compost $(n=156)$, $92(59 \%)$ only used peat-free, $12(8 \%)$ used mostly peat-free and $52(33 \%)$ did not use peatfree compost. Levels of compost, manure and topsoil all varied throughout the year, as demonstrated in Figure 5 showing monthly variation for people using each of these inputs.
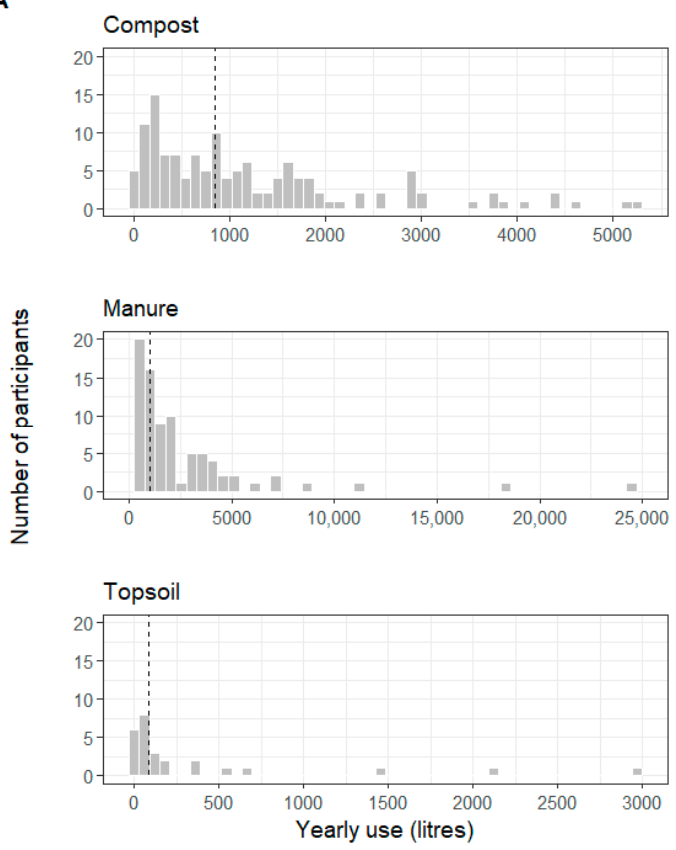

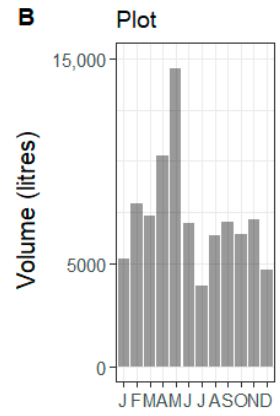

c

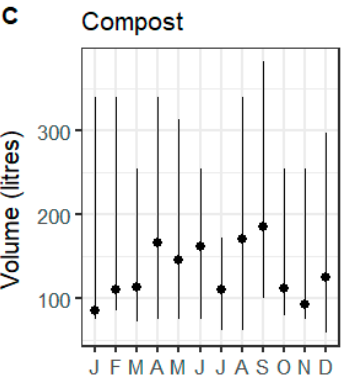

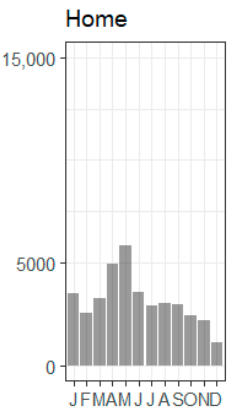

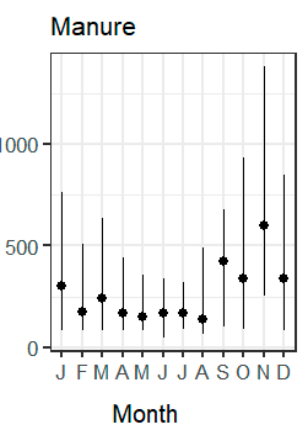

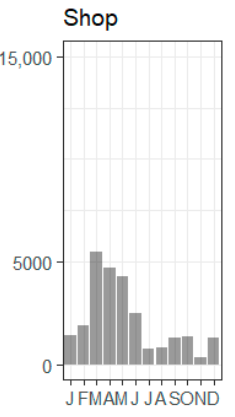
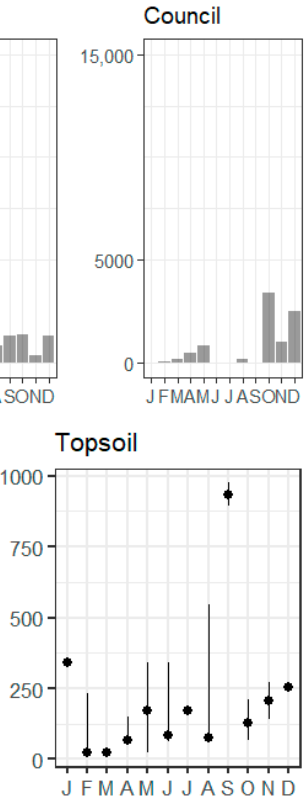

Figure 5. Use of compost, manure and topsoil by allotment gardeners ( $n=155)$. (A) Distribution of yearly use (litres) of compost, manure and topsoil with dashed lines indicating the median use of each resource. (B) Monthly total use of compost split by source (plot, home, shop or council). (C) Monthly median (points) and interquartile ranges (lines) of compost, manure and topsoil additions.

\subsection{Fertilisers, Pesticide and Weed Control}

Participants recorded a wide variety of fertiliser use (from organic and non-organic sources) as well as pest and weed control inputs. Frequency of inputs varied across the year and peaked in late spring and early summer (Figure 6). Fertiliser was the most commonly added of these inputs, with 131 participants using fertiliser at some point during the year, varying from once to 48 times. The median number of days on which participants applied fertiliser was 7, with the distribution skewed to a small number of participants applying particularly larger than average amounts. Pest control was applied by 120 participants, ranging from once to 31 times. Weed control was used by 66 people, ranging from once to 20 times (this count did not include hand weeding of plots). The median number of days on which pest control was applied was four days in the year, and the median number of days for application of weed control was twice. Similarly to fertiliser use, both pest and weed control were skewed towards a few participants whose gardening techniques involved much greater than average use (Figure 6). Table 1 shows the counts for the total number of days on which general categories of each of these applications was used; see Supplementary Materials for a full list of all the methods by which people fertilised their plots, and used pest and weed control. 


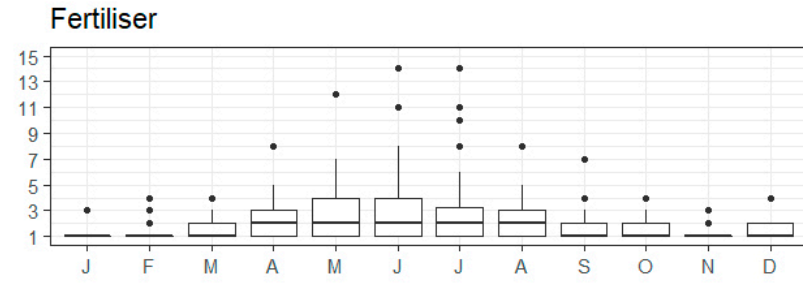

Pest control

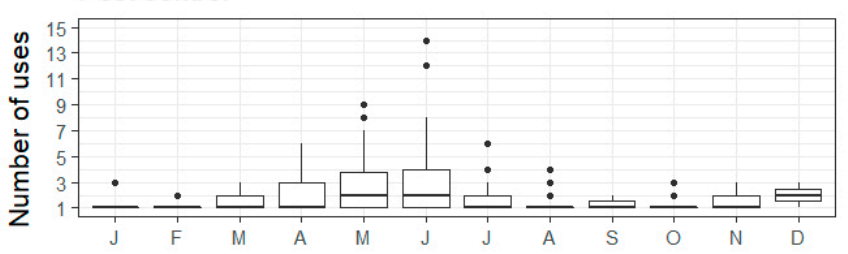

Weed control

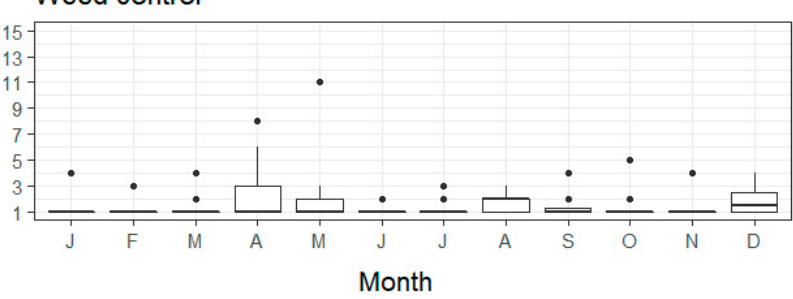

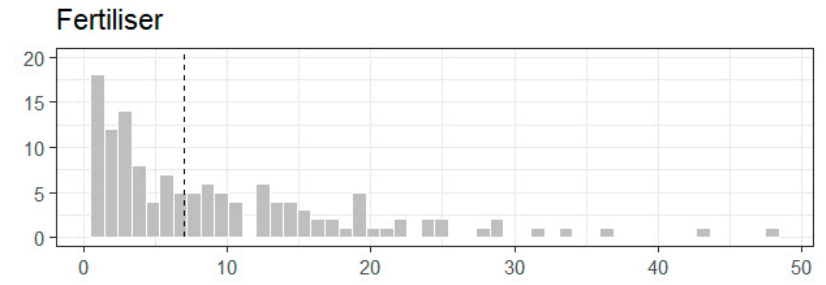

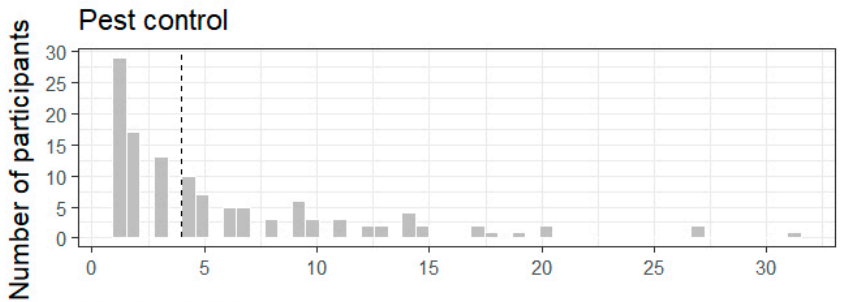

Weed control

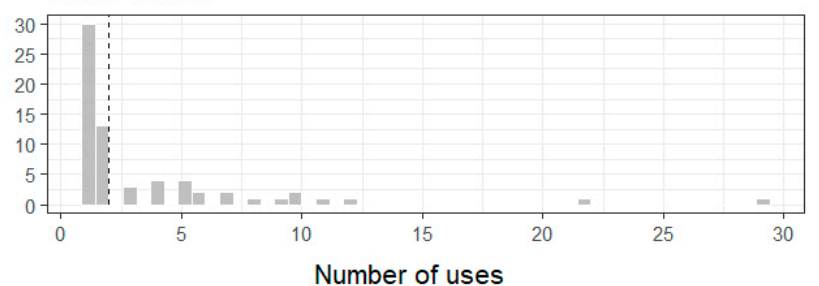

Figure 6. Fertiliser, pest control and weed control use on allotments $(n=162)$. (A) Monthly median and interquartile ranges of number of days on which fertilisers, pest control measures and weed control measures were applied (B) Distribution of number of days in the year on which fertiliser, pest control and weed control were applied. Dashed lines indicate median number of uses.

Table 1. General categories and number of days on which types of fertiliser, pest control and weed control were used on allotments from a total of 14,992 plot visits by 163 gardeners. Some types which were used once or twice did not fit into these categories and are excluded from the table; see Supplementary Materials for a full list and count of all types.

\begin{tabular}{|c|c|c|c|c|c|}
\hline \multicolumn{2}{|l|}{ Fertiliser } & \multicolumn{2}{|l|}{ Pest Control } & \multicolumn{2}{|l|}{ Weed Control } \\
\hline General Type & Number & General Type & Number & General Type & Number \\
\hline Branded, e.g., Tomorite & 358 & Pellets (primarily slug) & 530 & $\begin{array}{l}\text { Chemical weedkiller, e.g., } \\
\text { Roundup }\end{array}$ & 129 \\
\hline $\begin{array}{l}\text { Seaweed, comfrey and } \\
\text { nettles }\end{array}$ & 300 & Insecticide and poison & 91 & $\begin{array}{l}\text { Bark, cardboard and } \\
\text { woodchip }\end{array}$ & 74 \\
\hline Chicken manure pellets & 270 & $\begin{array}{l}\text { Homemade, e.g., washing } \\
\text { up liquid spray }\end{array}$ & 46 & Fabric, mesh and carpet & 21 \\
\hline Fish, blood and bone & 190 & Netting, fleece, and wire & 42 & Plastic & 15 \\
\hline $\begin{array}{l}\text { General (un- } \\
\text { branded/undisclosed brand) }\end{array}$ & 184 & $\begin{array}{l}\text { Traps, e.g., beer traps } \\
\text { for slugs }\end{array}$ & 27 & & \\
\hline Lime & 38 & Nematodes & 9 & & \\
\hline
\end{tabular}

\subsection{Overall Resource Requirements}

The above results allow us to estimate the average yearly resource use on allotment gardens per metre squared at the whole plot scale (i.e., including both cultivated areas and other infrastructure, such as paths-see earlier discussion in Section 2).

Overall, the average (median) allotment user would visit their plot 87 times, each visit involving travel of $1.6 \mathrm{~km}$ in each direction. This gave a total of $139 \mathrm{~km}$ travelled per year (with those journeys most likely to be made by car, or on foot, slightly less likely by bike, and rarely by public transport). They would pay $£ 37$ for the rent on their plot. Per 
square metre of their allotment, they would use $0.6 \mathrm{~h}$ of labour and $30.4 \mathrm{~L}$ of water over the year. If they used compost, manure or topsoil, their use per square metre would be 3.4 L of compost, $0.3 \mathrm{~L}$ of topsoil, and 3.9 $\mathrm{L}$ of manure. If they used additional fertilisers, pest control methods and weed control methods on top of hoeing and hand weeding, they would do this seven, four and two times, respectively, over the course of the year (Figure 7).

87 visits (139 km travel)

7 fertiliser additions

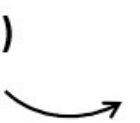

4 pest control additions

2 weed control additions

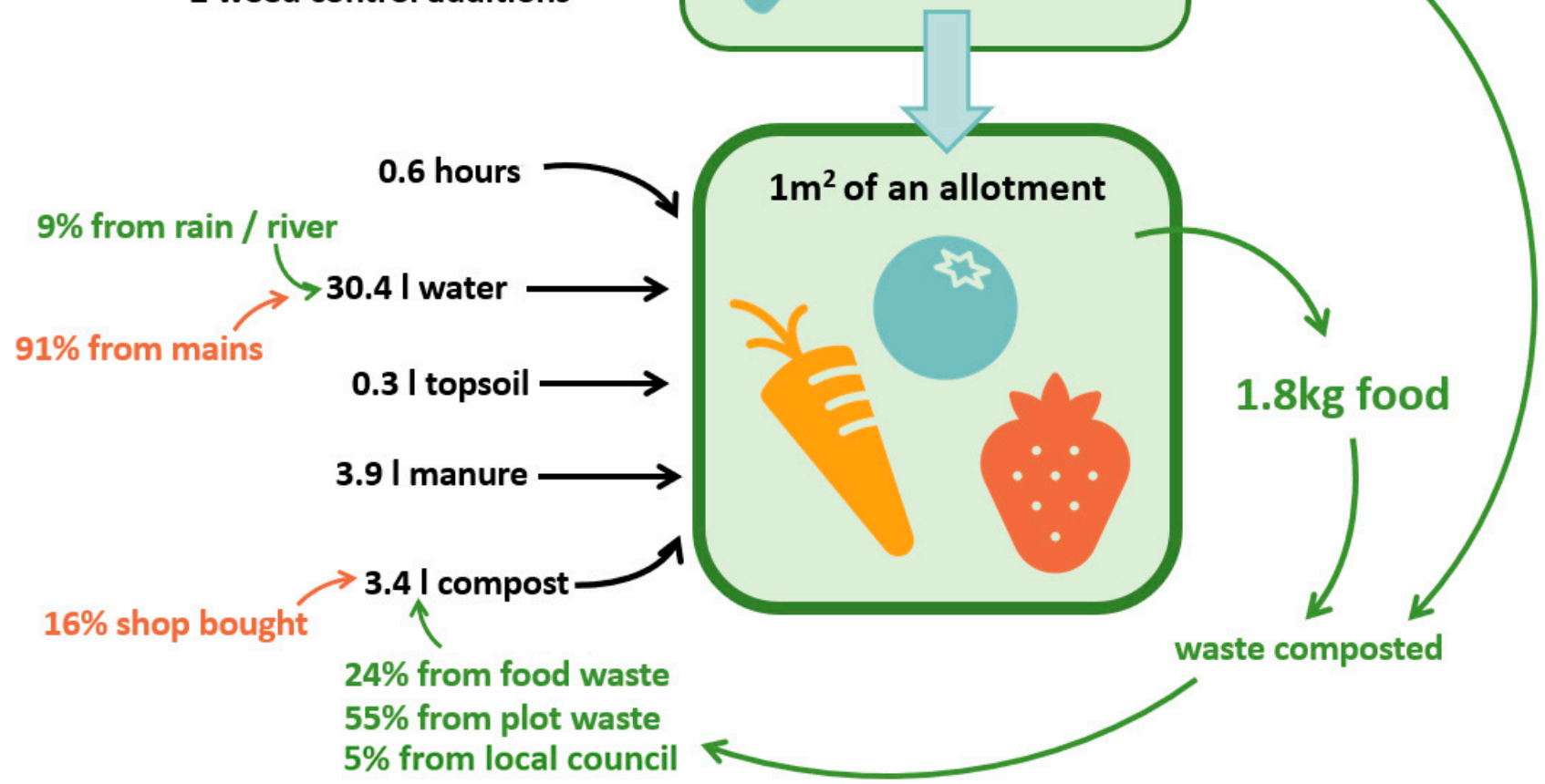

Figure 7. Yearly resource use on allotment plots, and specific requirements to produce $1 \mathrm{~kg}$ of fruit and vegetables on an allotment, demonstrating what proportion of recycled or collected and non-recycled resources are used in each input. Data use the median for each resource $(n=163)$.

Using some of the above results, we can also calculate the levels of some resources needed to produce one kilogram of fruit or vegetables. On average it is estimated that allotment gardeners produced an average yield of $1.8 \mathrm{~kg} \mathrm{~m}^{-2}$ over the entire area of an allotment [5]. Therefore, resource requirements per kilo of produce are $16.9 \mathrm{~L}$ of water, and, if the following are used, $1.9 \mathrm{~L}$ of compost, $0.2 \mathrm{~L}$ of topsoil, and $2.2 \mathrm{~L}$ of manure.

\section{Discussion}

$\mathrm{UH}$, in the form of allotment gardening, uses resources in a variety of forms. These resources are a necessary component of food production taking place in allotment gardens, which provide fresh produce for those involved, alongside other associated benefits and important ecosystem services [11-15]. Global agricultural land currently under-produces fruit and vegetables relative to global needs based on nutritional guidelines [41], and British vegetable production in tonnes has fallen for the past four years in a row [42]. UH presents an opportunity to increase the global supply of fruit and vegetables at a local level for urban residents. Here we present the first year-round investigation into resource requirements for allotment gardening, a key initial step in the assessment of the sustainability of this potentially important form of soil-based food production. Using a citizen science approach, we have derived a country-wide picture of the activities of 
allotment gardeners, including the seasonal variability in resource use and requirements. Combined with the work of [5], we were then able to determine the resource requirements to produce one kilogram of produce on an allotment. Resources varied in their roles and wider implications for allotment sustainability.

\subsection{Fertilisers, Weedkillers, Pesticides and Compost}

Previous research has found that allotment gardening maintains high levels of soil quality and its associated ecosystem services [35].Our results, showing relatively low incidences of chemical applications, and high levels of use of manure and compost, are consistent with this, demonstrating that allotment gardeners participate in management practices conducive to the maintenance of soil health. One element of these inputs is food and allotment waste. Whilst we are only just starting to quantify the capacity of UH to absorb urban waste [43], our research demonstrates that allotment gardeners are primarily sourcing their compost from plot or home food waste, diverting compostable waste from landfill or incineration to recycling on the allotment. Use of shop-bought compost was relatively low, and $67 \%$ of participants recorded that they used only, or mostly, peat-free compost, removing the greenhouse gas and habitat destruction costs associated with peat, which are orders of magnitude higher than for peat free alternatives [44]. Further to this, $83 \%$ of participants grew wholly or mostly organically (as self-reported), a proven method for the maintenance of soil health [45].

Our results detail a wide range of organic and non-organic fertilisers, pest control and weed control used by allotment gardeners, which present a challenge when attempting to understand the consequences of allotment management practices on an overall, national scale. Whilst many of the applications used by our participants were organic (such as seaweed), weedkillers such as glyphosate, and pest control methods such as slug pellets were also used. These may have negative consequences for some wildlife $[46,47]$. Overapplication of non-organic fertilisers also has negative consequences for long-term soil health, water, and potentially human health [48]. However, the median level of applications of all fertilisers, weedkillers and pest control was low. On a national or city-wide scale, problems could present if a particular allotment site had a high density of gardeners using greater-than-average biocides. Other management techniques such as the high levels of compost and manure addition detailed above suggest that allotment gardeners generally maintain good levels of soil health and wildlife-friendly gardening practices. Use of compost and manure mean soil nutrients are restored without an over-reliance on synthetic fertilisers, which helps maintain good soil quality [49]. In comparison to commercial arable farming in the UK, where pesticides and herbicides are applied an average of 34 times per year [50], and $99 \%$ of potato crops and $75 \%$ of brassica crops (for example) receive synthetic fertiliser applications [51], overall application levels of fertiliser, weedkillers and pesticides were very low on allotments.

\subsection{Water Use}

High soil quality also means that water use requirements of $\mathrm{UH}$ are likely to be lower than in commercial horticulture. In the UK, $34 \%$ of commercial horticultural crops are irrigated, and water use has been identified as a target for increasing sustainability and improving environmental impact [52]. Our results found that the average water use per square metre of an allotment was $30.4 \mathrm{~L}$. Per square metre of commercial horticulture, this figure rises to $49 \mathrm{~L}$ [52]. This suggests that allotment gardens are more conservative, and, with very low occurrences of the use of irrigation, more sustainable, in their water use that conventional horticultural farms.

However, our results may overestimate the typical water use on allotments over a longer period of time. For the UK, the summer of 2018 was the joint hottest on record [53]. A heatwave from May to August brought drought conditions to much of the country, and in some places broke records for the longest number of consecutive days without rainfall. Diary participants were fully aware of this, with many comments and observations 
regarding the summer weather (for example, diary entries from one participant: 24 June, 'No-one can remember when it last rained'; 18 July, 'No rain for at least two months'; 23 July, 'Plants are dying'). In July 2018, the UK experienced $54.3 \mathrm{~mm}$ of rainfall. This is much lower than the average of $88.5 \mathrm{~mm}$ experienced over the period 2014-2020 when excluding 2018 from the calculation [54]. The IPCC predicts that the UK will have more frequent hot, dry summers in the future due to climate change; models found that the 2018 heatwave was thirty times more likely to have occurred than if climate change had not been a factor [53]. The Met Office also predict that $50 \%$ of summers could mirror the 2018 heatwave in the future [55]. Our data on water use requirements are therefore both historically unusual, as more watering was required than in a year of typical rainfall, but also important in the context of future climate change and the resultant changing water use requirements of UH. Our results have clearly demonstrated that with dry conditions beginning in late spring and early summer, winter stocks of rainwater harvested by individual gardeners are insufficient in the majority of cases to meet the water demands of an allotment into the summer months.

\subsection{Resource Capture and Recycling}

These results suggest opportunities for a wider integration of UH into urban energy and materials flows in order to take advantage of potential opportunities for resource recycling in the urban system. There are a number of forms that this could take, including greywater recycling, demolition and construction waste material recycling for use in infrastructure, and diversion of compostable waste from other sources. Two which arise from this study are increasing the harvesting of rainwater and the capture of compostable waste. Considering the limitations to allotment gardeners' capacity to collect and store water, which was insufficient to meet the demands of the 2018 heatwave, it is important to understand whether this is a limitation of collecting potential, storage, or both. Allotments, by virtue of being collections of plots on sites with few buildings or other hard surfaces, provide limited scope for rainwater harvesting; small sheds or greenhouses are typically the only collecting surfaces available. It may be that this limits the potential for water collecting. However, it is also important to investigate opportunities for greater storage of winter rainfall, potentially at a site-wide or even community level, and the potential for water collected elsewhere (e.g., on buildings) to be diverted for UH use. British winters are becoming wetter (the most recent decade was 12\% wetter in winter than 1961-1990 [55]); February 2020 broke rainfall records across the country for the wettest February ever, as part of the wettest ever winter [56]. An opportunity for co-benefits therefore exists here. Expansion of water storage facilities across a city to help mitigate the flood risk from heavy rainfall winters could then be a source of water for UH during drier months. If $\mathrm{UH}$ is to be upscaled with its current reliance on mains water, the pressure on the urban water supply would be exacerbated. Therefore, it is key for policy makers to consider water reuse and harvesting when planning future UH sites. Further integration of UH into the sustainability fabric of a city could also utilise wastewater, if safely treated; this is another avenue that warrants further investigation $[57,58]$. However, the costs associated with collecting and treating water from such alternative sources may limit the viability of any such schemes $[57,58]$.

The capture of compostable waste on a citywide level is the second key opportunity, highlighted by this research, to increase the sustainability of UH and integrate urban resources. Whilst we found that the majority of an allotment gardener's compost comes from home and plot waste, some integration of wider urban compostable waste can also be seen in the $5.3 \%$ of compost used that was from local authority green waste sources. Both this municipal green waste, and a wider integration of home food waste from nongardeners to centralised compost sources that could be used in $\mathrm{UH}$, would further reduce the need for gardeners to purchase compost, and prevent the disposal to landfill or by incineration of compostable material by non-gardeners. This idea is in its infancy in practice but has the potential to reduce the pressure on landfill, save on costs of central 
waste management in cities, and recycle nutrients currently lost through waste [59]. Overall, with $83.9 \%$ of allotment gardeners' compost already coming from recycled sources, the inclination to use sustainable compost sources is high amongst gardeners and suggests they would be favourable to the introduction of other reused sources in the future. Just under half of our participants brought their home waste to compost on the plot, and just over half composted the waste from their plot itself (a lower number than that found by [35], who reported $95 \%$ of allotment gardeners composting plot waste on-site and 75\% adding household waste). This suggests a great deal of potential to expand the use of compost from personal and potentially municipal waste in the future. However, we do not know how many participants used their compostable home waste for their home gardens. High levels of home composting for gardens would reduce the potential amount available for UH. This also applies to participants who potentially brought $100 \%$ of their compostable waste to use on the plot and still needed to make purchases of commercial compost to have the amount they needed. Manure would probably continue to be sourced from animal agriculture in rural areas; however, city farms could also provide a source for this.

\subsection{Human Resources: Time, Money, and Travel}

One resource unquantified by our study is the amount of money that gardeners spend on their allotments beyond the price of their rent. An investigation into this could provide an important insight into whether there are financial barriers that may prevent those from lower incomes from participating in $\mathrm{UH}$, especially in light of recent research demonstrating that low-income areas have disproportionately suffered from allotment site closures over the past half century [27]. Our results demonstrate a huge variation in rent costs across the country, with the highest rates standing at $£ 280$ per year, compared to a lowest cost of $£ 0$. Gardening has been shown to be an important opportunity for more deprived communities to actively participate in creating their own food security nets as well as creating thriving neighbourhoods through the associated wellbeing and physical health benefits of participating in UH [60-62]. Therefore, an important policy consideration is the need to distribute food growing areas across a city in a way that ensures equitability of local access to these areas. Given the evident time commitments required for allotment gardening, it is understandable that using a car for transportation to the plot may be a preferred form of transport for people who are time-poor. With 95\% of walking trips under $2 \mathrm{~km}$ in length, our results suggest that if somebody lived further than this from their allotment, walking became too time consuming to be an effective mode of transportation. However, there was no significant relationship between the distance from their plot that somebody lived and the number of times they visited their plot. This therefore appears to necessitate access to a vehicle to successfully participate in UH if the cultivation space is more than $2 \mathrm{~km}$ from a person's residence. Ensuring that sites of urban food production are within walking distance for participants would enable non-car owners to participate in UH, as well as limiting the use of cars and their associated emissions and congestion impacts.

\section{Conclusions}

Understanding the resources required for food production, as seen in Figure 7, furthers our scientific understanding of the sustainability and resource costs of UH. It also has the potential to be used as an educational and informational tool for prospective urban gardeners. They can use this information to estimate their resource demands over a year depending on the size of their growing space; assess whether they possess the requisite spare time to participate in $\mathrm{UH}$; and help in planning for the resources they need throughout the year. We can assume that gardening management practices (bar travel) are broadly similar to other soil-based UH types, such as home gardening or community garden [17], meaning that our results are valuable for participants in a number of forms of UH beyond allotments.

Understanding the lifecycle demands of UH is of particular importance as interest in upscaling the amount of food production in cities grows. In order to understand the 
lifecycle demands of UH in this form, in the future, researchers should use the data presented here to ensure their chosen allotment gardens for study are representative of the national average resource use levels. Understanding can then be drawn down to the crop level, looking at variation in resource use across the most common crops grown by allotment gardeners [5], and research can answer the arising questions on whether selection of particular crops to grow would increase resource use efficiency and sustainability at the plot level. This would also enable more direct comparisons with resource use in conventional agricultural systems, on a crop-by-crop basis. However, recent research has noted the tendency of LCA analysis to under-represent the sustainability and resilience benefits, as well as ecosystem service provision potential, of conventional agriculture [63], so investigations of this nature must be conducted with a methodology that takes such benefits into account.

Further investigation into the resource requirements of different forms of UH could be combined with approaches such as that of combining citizen science, field mapping and GIS [26] or coupling own-grown yields with areal surveys [64], investigating the potential for upscaling a multiplicity of UH types across a city. Allotment gardening and equivalent soil-based UH in home gardens is the dominant form of UH in the UK. However, as interest in UH grows, especially as a commercial venture, it will become necessary to compile similar data regarding the resource demands of the full multiplicity of UH types, including hydroponic systems, rooftop gardens and so on. Most current UH in the UK is non-commercial, which has the benefit of making it less reliant on producing consistent levels of food year-round. As a result, the associated negative environmental impacts of food production (such as heating of greenhouses) may be reduced, giving more weight to positive environmental impacts [43]. A suite of data available to practitioners and policy makers that takes into account the resource needs of different forms of $\mathrm{UH}$, including commercial ventures that may need more costly environmental inputs, would be an invaluable tool to help site the most appropriate UH type in each available food growing space within a city. Previous research has demonstrated that allotment gardeners often share surplus produce with friends and family [65]; future research analysing the end location of harvests could bring an assessment of food miles into the picture of resource use sustainability.

UH has hitherto been an under-researched component of urban sustainability, and its place within the material flows of cities is poorly understood. As interest in upscaling $\mathrm{UH}$ to contribute to sustainable food production in cities grows, it is equally important to understand its resource demands. Our results suggest that there is the potential for high levels of sustainability: recycling rainwater, low pesticide use, recycling of household food waste and garden green waste, active travel, and the known health and wellbeing benefits of UH. Typical allotment management practices are conducive to the maintenance of soil health and ecosystem services, with an emphasis on the use of compost and manure. However, it is also clear that this potential is not always realised as fully as it could be. Opportunities exist to further integrate UH into citywide resource use, for example by increasing the harvesting of rainwater to reduce the demands of UH on mains water supplies, or by spatial planning of UH sites to minimise car travel. These results help to develop a more holistic picture of $\mathrm{UH}$, and provide guidance for policy makers and practitioners seeking to integrate UH into the development of more sustainable cities.

Supplementary Materials: The following are available online at https:/ /www.mdpi.com/2071-1 050/13/5/2628/s1, Figure S1: General questions asked about allotments; Table S1: Fertilisers, pest control and weed control methods used by allotment gardeners, with frequency of applications (count of all days applied for all participants).

Author Contributions: Conceptualisation, M.C.D., P.H.W. and J.L.E.; methodology, M.C.D., P.H.W. and J.L.E.; formal analysis, M.C.D.; investigation, M.C.D.; resources, M.C.D., P.H.W. and J.L.E.; data curation, M.C.D.; writing-original draft preparation, M.C.D.; writing-review and editing, M.C.D., J.L.E. and P.H.W.; supervision, P.H.W. and J.L.E.; project administration, M.C.D.; funding 
acquisition, M.C.D., P.H.W. and J.L.E. All authors have read and agreed to the published version of the manuscript.

Funding: This research was funded by EPSRC Living with Environmental Change Fellowship Grant, grant number EP/N030095/1 and The University of Sheffield Department of Animal and Plant Sciences PhD-T, grant number 325059.

Institutional Review Board Statement: Not applicable.

Informed Consent Statement: Informed consent was obtained from all subjects involved in the study.

Data Availability Statement: Data available upon request.

Acknowledgments: Contains data supplied by Natural Environment Research Council. We acknowledge gratefully all our citizen science participants who generously gave up their time to participate in this project.

Conflicts of Interest: The authors declare no conflict of interest. The funders had no role in the design of the study; in the collection, analyses, or interpretation of data; in the writing of the manuscript, or in the decision to publish the results.

\section{References}

1. United Nations. World Urbanization Prospects: The 2018 Revision; United Nations Publications: New York, NY, USA, 2019.

2. Food and Agriculture Organization of the United Nations. COVID-19 and the Risk to Food Supply Chains: How to Respond? FAO: Rome, Italy, 2020.

3. Goldstein, B.P.; Birkved, M.; Fernandez, J.E.; Hauschild, M. Surveying the environmental footprint of urban food consumption. J. Ind. Ecol. 2017, 21, 151-165. [CrossRef]

4. Benis, K.; Ferrão, P. Potential mitigation of the environmental impacts of food systems through urban and peri-urban agriculture (UPA)—A life cycle assessment approach. J. Clean. Prod. 2017, 140, 784-795. [CrossRef]

5. Edmondson, J.L.; Cunningham, H.; Tingley, D.O.D.; Dobson, M.C.; Grafius, D.R.; Leake, J.R.; McHugh, N.; Nickles, J.; Phoenix, G.K.; Ryan, A.J.; et al. The hidden potential of urban horticulture. Nat. Food 2020, 1, 155-159. [CrossRef]

6. Mcdougall, R.; Rader, R.; Kristiansen, P. Urban agriculture could provide 15\% of food supply to Sydney, Australia, under expanded land use scenarios. Land Use Policy 2020, 94, 104554. [CrossRef]

7. Lovell, S.T. Multifunctional urban agriculture for sustainable land use planning in the United States. Sustainability 2010, 2, 2499-2522. [CrossRef]

8. Milan Urban Food Policy Pact. Signatory Cities. 2020. Available online: http:/ / www.milanurbanfoodpolicypact.org/signatorycities / (accessed on 24 August 2020).

9. Sustainable Food Places. Members. 2020. Available online: https://www.sustainablefoodplaces.org/members/ (accessed on 24 August 2020).

10. McClintock, N. Why farm the city? Theorizing urban agriculture through a lens of metabolic rift. Camb. J. Reg. Econ. Soc. 2010, 3, 191-207. [CrossRef]

11. McClintock, N.; Cooper, J.; Khandeshi, S. Assessing the potential contribution of vacant land to urban vegetable production and consumption in Oakland, California. Landsc. Urban Plan. 2013, 111, 46-58. [CrossRef]

12. Lin, B.B.; Philpott, S.M.; Jha, S. The future of urban agriculture and biodiversity-ecosystem services: Challenges and next steps. Basic Appl. Ecol. 2015, 16, 189-201. [CrossRef]

13. Speak, A.; Mizgajski, A.; Borysiak, J. Allotment gardens and parks: Provision of ecosystem services with an emphasis on biodiversity. Urban For. Urban Green. 2015, 14, 772-781. [CrossRef]

14. Webber, J.; Hinds, J.; Camic, P.M. The well-being of allotment gardeners: A Mixed methodological study. Ecopsychology 2015, 7, 20-28. [CrossRef]

15. Borysiak, J.; Mizgajski, A.; Speak, A. Floral biodiversity of allotment gardens and its contribution to urban green infrastructure. Urban Ecosyst. 2017, 20, 323-335. [CrossRef]

16. Maye, D. 'Smart food city': Conceptual relations between smart city planning, urban food systems and innovation theory. City Cult. Soc. 2019, 16, 18-24. [CrossRef]

17. Goldstein, B.; Hauschild, M.; Fernández, J.; Birkved, M. Urban versus conventional agriculture, taxonomy of resource profiles: A review. Agron. Sustain. Dev. 2016, 36,1-19. [CrossRef]

18. Kulak, M.; Graves, A.; Chatterton, J. Reducing greenhouse gas emissions with urban agriculture: A life cycle assessment perspective. Landsc. Urban Plan. 2013, 111, 68-78. [CrossRef]

19. Sanyé-Mengual, E.; Oliver-Solà, J.; Montero, J.I.; Rieradevall, J. An environmental and economic life cycle assessment of rooftop greenhouse (RTG) implementation in Barcelona, Spain. Assessing new forms of urban agriculture from the greenhouse structure to the final product level. Int. J. Life Cycle Assess. 2015, 20, 350-366. [CrossRef]

20. Sanyé-Mengual, E.; Gasperi, D.; Michelon, N.; Orsini, F.; Ponchia, G.; Gianquinto, G. Eco-efficiency assessment and food security potential of home gardening: A case study in Padua, Italy. Sustainability 2018, 10, 2124. [CrossRef] 
21. Goldstein, B.P.; Hauschild, M.Z.; Fernández, J.E.; Birkved, M. Contributions of local farming to urban sustainability in the northeast united states. Environ. Sci. Technol. 2017, 51, 7340-7349. [CrossRef]

22. Mohareb, E.; Heller, M.; Novak, P.; Goldstein, B.; Fonoll, X.; Raskin, L. Considerations for reducing food system energy demand while scaling up urban agriculture. Environ. Res. Lett. 2017, 12, 125004. [CrossRef]

23. Crouch, D.; Ward, C. The Allotment: Its Landscape and Culture; Five Leaves Publications: Nottingham, UK, 1997.

24. Acton, L. Growing Space: A History of the Allotment Movement; Five Leaves Publications: Nottingham, UK, 2015.

25. Campbell, M.; Campbell, I. Allotment waiting lists in England 2013. Transition Town West Kirby, National Society of Allotment and Leisure Gardeners, United Kingdom. Available online: http://www.transitiontownwestkirby.org.uk/files/ttwk_nsalg_ survey_2013.pdf (accessed on 28 August 2020).

26. Edmondson, J.L.; Childs, D.Z.; Dobson, M.C.; Gaston, K.J.; Warren, P.H.; Leake, J.R. Feeding a city-Leicester as a case study of the importance of allotments for horticultural production in the UK. Sci. Total Environ. 2020, 705, 135930. [CrossRef]

27. Dobson, M.C.; Edmondson, J.L.; Warren, P.H. Urban food cultivation in the United Kingdom: Quantifying loss of allotment land and identifying potential for restoration. Landsc. Urban Plan. 2020, 199, 103803. [CrossRef]

28. Niala, J. Dig for vitality: UK urban allotments as a health-promoting response to COVID-19. Cities Health 2020, 1-5. [CrossRef]

29. Grewal, S.S.; Grewal, P.S. Can cities become self-reliant in food? Cities 2012, 29, 1-11. [CrossRef]

30. Petit-Boix, A.; Llorach-Massana, P.; Sanjuan-Delmás, D.; Sierra-Pérez, J.; Vinyes, E.; Gabarrell, X.; Rieradevall, J.; Sanyé-Mengual, E. Application of life cycle thinking towards sustainable cities: A review. J. Clean. Prod. 2017, 166, 939-951. [CrossRef]

31. Environmental Protection Agency. Composting at home. 2020. Available online: https://www.epa.gov/recycle/compostinghome (accessed on 30 March 2020).

32. Chen, C.; Chaudhary, A.; Mathys, A. Nutritional and environmental losses embedded in global food waste. Resour. Conserv. Recycl. 2020, 160, 104912. [CrossRef]

33. Gondhalekar, D.; Ramsauer, T. Nexus city: Operationalizing the urban water-energy-food nexus for climate change adaptation in Munich, Germany. Urban Clim. 2017, 19, 28-40. [CrossRef]

34. Pataki, D.E.; Carreiro, M.M.; Cherrier, J.; Grulke, N.E.; Jennings, V.; Pincetl, S.; Pouyat, R.V.; Whitlow, T.H.; Zipperer, W.C. Coupling biogeochemical cycles in urban environments: Ecosystem services, green solutions, and misconceptions. Front. Ecol. Environ. 2011, 9, 27-36. [CrossRef]

35. Edmondson, J.L.; Davies, Z.G.; Gaston, K.J.; Leake, J.R. Urban cultivation in allotments maintains soil qualities adversely affected by conventional agriculture. J. Appl. Ecol. 2014, 51, 880-889. [CrossRef] [PubMed]

36. Met Office. UK Climate Averages. 2021. Available online: https://www.metoffice.gov.uk/research/climate/maps-and-data/ukclimate-averages (accessed on 10 February 2021).

37. Carbon Brief. England's Growing Season Now Almost a Month Longer, Says Met Office. 2021. Available online: https: //www.carbonbrief.org/englands-growing-season-now-almost-a-month-longer-says-met-office (accessed on 10 February 2021).

38. Reis, S.; Liska, T.; Steinle, S.; Carnell, E.; Leave, D.; Roberts, E.; Veino, M.; Beck, R.; Dragosits, U. UK Gridded Population 2011 Based on Census 2011 and Land Cover Map 2015; UK Centre for Ecology \& Hydrology: Midlothian, UK, 2017; Available online: https: / / doi.org/10.5285/0995e94d-6d42-40c1-8ed4-5090d82471e1 (accessed on 1 March 2021).

39. Swan Products. The Flow Rate of a Garden Hose. 2020. Available online: https:/ /www.swanhose.com/garden-hose-flow-rate-s / 1952.htm (accessed on 8 July 2020).

40. R Core Team. R: A Language and Environment for Statistical Computing; R Foundation for Statistical Computing: Vienna, Austria, 2018; Available online: https: / /www.R-project.org (accessed on 1 March 2021).

41. Kc, K.B.; Dias, G.M.; Veeramani, A.; Swanton, C.J.; Fraser, D.; Steinke, D.; Lee, E.; Wittman, H.; Farber, J.M.; Dunfield, K.; et al. When too much isn't enough: Does current food production meet global nutritional needs? PLoS ONE 2018, 13, e0205683. [CrossRef]

42. Department for Environment Food and Rural Affairs. Horticulture Statistics 2019. 2020. Available online: https://assets. publishing.service.gov.uk/government/uploads/system/uploads/attachment_data/file/901689/hort-report-17jul20.pdf (accessed on 6 November 2020).

43. Goldstein, B.P.; Hauschild, M.Z.; Fernández, J.; Birkved, M. Testing the environmental performance of urban agriculture as a food supply in northern climates. J. Clean. Prod. 2016, 135, 984-994. [CrossRef]

44. Boldrin, A.; Andersen, J.K.; Møller, J.; Christensen, T.H.; Favoino, E. Composting and compost utilization: Accounting of greenhouse gases and global warming contributions. Waste Manag. Res. 2009, 27, 800-812. [CrossRef]

45. Lorenz, K. Organic urban agriculture. Soil Sci. 2015, 180, 146-153. [CrossRef]

46. Purvis, G.; Bannon, J.W. Non-target effects of repeated methiocarb slug pellet application on carabid beetle (Coleoptera: Carabidae) activity in winter-sown cereals. Ann. Appl. Biol. 1992, 121, 401-422. [CrossRef]

47. Relyea, R.A. The lethal impact of roundup on aquatic and terrestrial amphibians. Ecol. Appl. 2005, 15, 1118-1124. [CrossRef]

48. Altieri, M.A.; Companioni, N.; Cañizares, K.; Murphy, C.; Rosset, P.; Bourque, M.; Nicholls, C.I. The greening of the "barrios": Urban agriculture for food security in Cuba. Agric. Hum. Values 1999, 16, 131-140. [CrossRef]

49. Beniston, J.; Lal, R. Improving soil quality for urban agriculture in the North Central, U.S. In Carbon Sequestration in Urban Ecosystems; Augustin, B., Lal, R., Eds.; Springer International Publishing: Geneva, Switzerland, 2011; pp. $279-313$. 
50. Garthwaite, D.; Ridley, L.; Mace, A.; Parrish, G.; Barker, I.; Rainford, J.; MacArthur, R. Pesticide Usage Survey Report 284: Arable Crops in the United Kingdom 2018. Available online: https://secure.fera.defra.gov.uk/pusstats/surveys/documents/arable201 8.pdf (accessed on 6 August 2020).

51. Department for Environment, Food and Rural Affairs. The British Survey of Fertiliser Practice: Fertiliser Use on Farm Crops for Crop Year 2019; Department for Environment, Food and Rural Affairs: London, UK, 2019. Available online: https://www.gov.uk/ government/statistics/british-survey-of-fertiliser-practice-2019 (accessed on 6 August 2020).

52. Knox, J.; Rodriguez-Diaz, J.; Weatherhead, E.K.; Kay, M. Development of a water-use strategy for horticulture in England and Wales-A case study. J. Hortic. Sci. Biotechnol. 2010, 85, 89-93. [CrossRef]

53. Met Office. Chance of Summer Heatwaves Now Thirty Times More Likely. 2018. Available online: https:/ /www.metoffice.gov. uk/about-us/press-office/news/weather-and-climate/2018/2018-uk-summer-heatwave (accessed on 8 July 2020).

54. Statista. Total Monthly Rainfall in the United Kingdom (UK) from 2014 to 2020. 2021. Available online: https: / / www.statista. com/statistics/584914/monthly-rainfall-in-uk/ (accessed on 10 February 2021).

55. Met Office. UK Climate Projections: Headline Findings. 2019. Available online: https://www.metoffice.gov.uk/binaries/content/ assets/metofficegovuk/pdf/research/ukcp/ukcp-headline-findings-v2.pdf (accessed on 30 March 2020).

56. Met Office. Record Breaking Rainfall. 2020. Available online: https://www.metoffice.gov.uk/about-us/press-office/news/ weather-and-climate/2020/2020-winter-february-stats (accessed on 30 March 2020).

57. Buechler, S.; Mekala, G.D.; Keraita, B. Wastewater use for urban and peri-urban agriculture. In Cities Farming for the Future: Urban Agriculture for Green and Productive Cities; van Veenhuizen, E., Ed.; FUAF Foundation: Hague, The Netherlands, 2006.

58. Miller-Robbie, L.; Ramaswami, A.; Amerasinghe, P. Wastewater treatment and reuse in urban agriculture: Exploring the food, energy, water, and health nexus in Hyderabad, India. Environ. Res. Lett. 2017, 12, 075005. [CrossRef]

59. De Zeeuw, H.; Van Veenhuizen, R.; Dubbeling, M. The role of urban agriculture in building resilient cities in developing countries. J. Agric. Sci. 2011, 149, 153-163. [CrossRef]

60. Travaline, K.; Hunold, C. Urban agriculture and ecological citizenship in Philadelphia. Local Environ. 2010, 15, 581-590. [CrossRef]

61. Milbourne, P. Everyday (in)justices and ordinary environmentalisms: Community gardening in disadvantaged urban neighbourhoods. Local Environ. 2012, 17, 943-957. [CrossRef]

62. Poulsen, M.N.; Hulland, K.R.S.; Gulas, C.A.; Pham, H.; Dalglish, S.L.; Wilkinson, R.K.; Winch, P.J. Growing an urban oasis: A qualitative study of the perceived benefits of community gardening in Baltimore, Maryland. Cult. Agric. Food Environ. 2014, 36, 69-82. [CrossRef]

63. Van Der Werf, H.M.G.; Knudsen, M.T.; Cederberg, C. Towards better representation of organic agriculture in life cycle assessment. Nat. Sustain. 2020, 3, 419-425. [CrossRef]

64. Grafius, D.R.; Edmondson, J.L.; Norton, B.A.; Clark, R.; Mears, M.; Leake, J.R.; Corstanje, R.; Harris, J.A.; Warren, P.H. Estimating food production in an urban landscape. Sci. Rep. 2020, 10, 1-9. [CrossRef] [PubMed]

65. Dobson, M.C.; Reynolds, C.; Warren, P.H.; Edmondson, J.L. "My little piece of the planet": The multiplicity of well-being benefits from allotment gardening. Br. Food J. 2020, 123, 1012-1023. [CrossRef] 